\title{
Making Nutritious Gluten-Free Foods from Quinoa Seeds and Its Flours ${ }^{+}$
}

\author{
Patricia Miranda Villa ${ }^{1,2}$, Natalia Cervilla ${ }^{1,3}$, Romina Mufari ${ }^{1,4}$, Antonella Bergesse ${ }^{1,2}$ \\ and Edgardo Calandri 1,3,* \\ 1 Instituto de Ciencia y Tecnología de los Alimentos (ICTA)-FCEFyN-UNC, Córdoba 5000, Argentina; \\ pmirandavilla@gmail.com (P.M.V.); lic.cervillanatalia@gmail.com (N.C.); \\ romi_mufari@hotmail.com (R.M.); anto_bergesse@hotmail.com (A.B.) \\ 2 Instituto de Ciencia y Tecnología de los Alimentos Córdoba (ICYTAC-CONICET), \\ Córdoba 5000, Argentina \\ 3 Escuela de Nutrición-Facultad de Ciencias Médicas-UNC, Córdoba 5000, Argentina \\ 4 Instituto de Investigaciones Biológicas y Tecnológicas (IIBYT-CONICET), Córdoba 5000, Argentina \\ * Correspondence: edgardo.calandri@unc.edu.ar \\ + Presented at the 2nd International Conference of Ia ValSe-Food Network, Lisbon, Portugal, \\ 21-22 October 2019.
}

Published: 5 August 2020

\begin{abstract}
Celiac disease is affecting around 1\% of the world population and an effective treatment needs to exclude gluten. Quinoa is a high-quality gluten-free protein, and starch-rich endosperm, like the cereals. Protein contents and theoretical Protein Digestibility Corrected Amino Acid Score (PDCAAS) were evaluated in quinoas from Northwest and Centre of Argentina. A batter-type gluten-free quinoa bread was developed, showing good volume, taste, nutritional quality and a good long-lasting texture. Malted quinoa seeds' quality indicators rose until $48 \mathrm{~h}$ of germination; after that, an unpleasant taste was developed. Muffins made with that flour showed acceptable taste.
\end{abstract}

Keywords: amino acids; breads; germinates; muffins; proteins; quinoa

\section{Introduction}

Celiac disease is one of syndromes associated with irritable bowel and the most important of the enteropathies related to gluten [1]. Quinoa seeds possess a high-quality gluten-free protein and also have a starch rich endosperm, which makes this grain resembles cereals, and for this reason, it is usually called a pseudocereal. Quinoa protein has high levels of the essential amino acids and also is a good source of fiber, minerals and antioxidants [2]; but the lack of prolamins preclude quinoa protein from keeping the particular structure of bread crumb [3] and must be replace by starches and gums [4]. Therefore, the preparation of gluten-free breads requires the help of technology in food to satisfy the expectations of consumers.

The malting of seeds, which consists of allowing their germination in a controlled manner, can improve the absorption of nutrients because biochemical processes, which start when the seeds are moistened, release substances such as free amino acids, simple sugars and fatty acids, small molecules that easily overpass the intestinal epithelium.

The present work reassembles the studies accomplished by the group with quinoa seeds of the Centre and Northwest of Argentina and its employ in the development of batter type, gluten-free breads and muffins, with a focus on the nutritional quality of the products but also improving their taste and palatability. 


\section{Materials and Methods}

\subsection{Raw Materials}

Northwest quinoa seeds were harvested from departments Molinos (2007-2008) and La Poma (2009-2011), Province of Salta, Argentina. Quinoas from the Centre region were originally Chilean "sea level" ecotype, varieties - Pichaman, Faro and Baer-cultivated in Río Cuarto, Argentina (2011). Bread preparation: quinoa, lupin and rice flours, hydroxypropyl methylcellulose (HPMC), sodium stearoyl lactylate (SSL), sugar and salt were mixed dry into a bowl. Fresh yeast was added, previously dispersed in warm water $\left(28^{\circ} \mathrm{C}\right)$, while mixing in a planetary mixer $(280 \mathrm{rpm}, 5 \mathrm{~min})$. Water addition was completed in this step. The final mixture was loaded in a mold and leavened at $35^{\circ} \mathrm{C}$ and relative humidity of $60 \%$ for $1 \mathrm{~h}$. Finally, the dough was placed in the oven for $35 \mathrm{~min}$ at $180{ }^{\circ} \mathrm{C}$. The bread loaf was left to cool at room temperature for $2 \mathrm{~h}$ before analysis.

\subsection{Gravimetric Measures}

The tests were carried out as described Cervilla et al. [5], Proximal Analysis, amino acid profile, Chemical Scoring (CS) and protein digestibility corrected amino acid score (PDCAAS), as described in Cervilla et al. [6]; the physical characteristics of products were determined as in Mufari et al. [7]; affective testing (consumer testing) and statistical analysis applied according to in Miranda-Villa et al. [8].

\section{Results and Discussion}

\subsection{Physical Properties}

Northern seeds were larger than those of the central region (Table 1). The weight of 1000 seeds (W1000) varied from 2.05 to $2.70 \mathrm{~g}$ for the central region, quite different to the northern ones, with values no lesser than $3.0 \mathrm{~g}$ for one thousand seeds, but the bulk density fluctuated between 0.55 and $0.73 \mathrm{~g} \mathrm{~mL}^{-1}$, without a clear distinction between seed types. The size for northern seeds (equivalent diameter) was between 1.64 and $2.01 \mathrm{~mm}$ and can be classified as medium to large size, according to IBNORCA [5], while seeds for central region should be considered as just medium size. The apparent density values (Table 1) provide useful information for the analysis of heat transfer through grains, in quality control, and in the evaluation, calculation and design of transport systems, cleaning and classification. Real density results are important in the design of storage, packaging, dehydration and transportation systems. 
Table 1. Gravimetric, dimensional properties and proximal composition of quinoa seeds a.

\begin{tabular}{|c|c|c|c|c|c|c|c|c|c|c|c|}
\hline Code $^{b}$ & $\begin{array}{c}\begin{array}{c}1000 \text { Seeds } \\
\text { Weight }\end{array} \\
\text { (g) } \\
\end{array}$ & $\begin{array}{c}\begin{array}{c}\text { True } \\
\text { Density }\end{array} \\
(\mathrm{g} / \mathrm{mL}) \\
\end{array}$ & $\begin{array}{c}\text { Bulk Density } \\
(\mathrm{g} / \mathrm{mL}) \\
\end{array}$ & $\begin{array}{c}\mathrm{d}_{1} \\
(\mathrm{~mm}) \\
\end{array}$ & $\begin{array}{c}\mathrm{d}_{2} \\
(\mathrm{~mm}) \\
\end{array}$ & $\begin{array}{c}\text { e } \\
(\mathrm{mm})\end{array}$ & $\begin{array}{c}\begin{array}{c}\text { Equivalent } \\
\text { Diameter }\end{array} \\
(\mathrm{mm}) \\
\end{array}$ & Ash & Lipids & Carbohyd & Poteins \\
\hline \multicolumn{12}{|c|}{ CENTRAL REGION SEEDS } \\
\hline PCh & $2.47 \pm 0.01 \mathrm{~b}$ & 1.01629272 & $0.554 \pm 0.04 \mathrm{~d}$ & $1.88 \pm 0.15 \mathrm{a}$ & $1.91 \pm 0.17 \mathrm{a}$ & $1.12 \pm 0.17 \mathrm{a}$ & $1.59 \pm 0.15 \mathrm{a}$ & $3.51 \pm 0.21 \mathrm{c}$ & $6.54 \pm 0.04 \mathrm{c}$ & $72.33 \pm 0.51$ & $17.18 \pm 0.25 \mathrm{a}$ \\
\hline $\mathrm{P}_{1} \mathrm{Rc}$ & $2.13 \pm 0.01 \mathrm{a}$ & 0.98586377 & $0.730 \pm 0.01 \mathrm{a}$ & $1.74 \pm 0.11 \mathrm{c}$ & $1.81 \pm 0.12 \mathrm{~b}$ & $1.00 \pm 0.10 \mathrm{c}$ & $1.47 \pm 0.10 \mathrm{~b}$ & $4.31 \pm 0.22 \mathrm{a}$ & $6.43 \pm 0.04 \mathrm{c}$ & $70.46 \pm 0.42$ & $18.25 \pm 0.14 \mathrm{a}$ \\
\hline $\mathrm{P}_{2} \mathrm{Rc}$ & $2.70 \pm 0.02 \mathrm{a}$ & 1.21518085 & $0.619 \pm 0.01 \mathrm{c}$ & $1.90 \pm 0.11 \mathrm{a}$ & $1.93 \pm 0.13 \mathrm{a}$ & $1.14 \pm 0.15 \mathrm{a}$ & $1.61 \pm 0.12 \mathrm{a}$ & $3.39 \pm 0.04 \mathrm{c}$ & $6.49 \pm 0.04 \mathrm{c}$ & $72.02 \pm 0.58$ & $17.64 \pm 0.45 \mathrm{a}$ \\
\hline $\mathrm{FCh}$ & $2.44 \pm 0.01 \mathrm{~b}$ & 1.07205692 & $0.687 \pm 0.01 \mathrm{~b}$ & $1.76 \pm 0.17 \mathrm{c}$ & $1.83 \pm 0.15 b$ & $1.06 \pm 0.14 b$ & $1.51 \pm 0.14 \mathrm{~b}$ & $4.02 \pm 0.10 \mathrm{~b}$ & $6.16 \pm 0.17 \mathrm{~d}$ & $73.68 \pm 0.52$ & $15.68 \pm 0.17 \mathrm{~b}$ \\
\hline $\mathrm{F}_{1} \mathrm{Rc}$ & $2.16 \pm 0.01 \mathrm{c}$ & 1.23720517 & $0.589 \pm 0.02 \mathrm{~d}$ & $1.80 \pm 0.13 \mathrm{~b}$ & $1.84 \pm 0.14 \mathrm{~b}$ & $1.00 \pm 0.18 \mathrm{c}$ & $1.42 \pm 0.13 \mathrm{~b}$ & $4.43 \pm 0.16 \mathrm{a}$ & $6.92 \pm 0.17 \mathrm{~b}$ & $70.28 \pm 1.95$ & $17.61 \pm 1.49 \mathrm{a}$ \\
\hline $\mathrm{F}_{2} \mathrm{Rc}$ & $2.20 \pm 0.01 \mathrm{c}$ & 1.06173958 & $0.744 \pm 0.01 \mathrm{a}$ & $1.74 \pm 0.13 \mathrm{c}$ & $1.78 \pm 0.11 \mathrm{~b}$ & $1.01 \pm 0.11 \mathrm{c}$ & $1.46 \pm 0.10 \mathrm{~b}$ & $3.89 \pm 0.03 b$ & $8.19 \pm 0.05 \mathrm{a}$ & $70.50 \pm 0.29$ & $16.95 \pm 0.18 \mathrm{a}$ \\
\hline $\mathrm{BCh}$ & $2.29 \pm 0.01 \mathrm{c}$ & 0.98119775 & $0.577 \pm 0.02 \mathrm{~d}$ & $1.70 \pm 0.12 \mathrm{c}$ & $1.78 b \pm 0.15 b$ & $0.97 \pm 0.15 c$ & $1.43 \pm 0.13 \mathrm{c}$ & $3.56 \pm 0.15 \mathrm{c}$ & $7.05 \pm 0.01 \mathrm{~b}$ & $71.44 \pm 0.61$ & $17.41 \pm 0.28 \mathrm{a}$ \\
\hline $\mathrm{B}_{1} \mathrm{Rc}$ & $2.14 \pm 0.01 \mathrm{c}$ & 1.21661019 & $0.729 \pm 0.01 \mathrm{a}$ & $1.72 \pm 0.18 \mathrm{c}$ & $1.77 \pm 0.12 b$ & $0.98 \pm 0.10 \mathrm{c}$ & $1.44 \pm 0.11 \mathrm{c}$ & $3.97 \pm 0.04 \mathrm{~b}$ & $7.27 \pm 0.00 \mathrm{~b}$ & $71.40 \pm 0.18$ & $16.87 \pm 0.13 \mathrm{a}$ \\
\hline $\mathrm{B}_{2} \mathrm{Rc}$ & $2.05 \pm 0.01 \mathrm{c}$ & 1.21884051 & $0.715 \pm 0.01 \mathrm{a}$ & $1.70 \pm 0.11 \mathrm{c}$ & $1.75 \pm 0.14 \mathrm{~b}$ & $0.96 \pm 0.11 \mathrm{c}$ & $1.42 \pm 0.11 \mathrm{c}$ & $4.14 \pm 0.07 \mathrm{~b}$ & $5.83 \pm 0.24 \mathrm{e}$ & $72.30 \pm 1.23$ & $18.25 \pm 0.14 \mathrm{a}$ \\
\hline \multicolumn{12}{|c|}{ NORTHERN SEEDS c } \\
\hline 2007 & $3.2 \pm 0.1 \mathrm{~b}$ & $1.19 \pm 0.10 \mathrm{a}$ & $0.69 \pm 0.01 \mathrm{~d}$ & $2.08 \pm 0.10 \mathrm{a}$ & $2.12 \pm 0.13 \mathrm{a}$ & $1.00 \pm 0.10 \mathrm{a}$ & $1.64 \pm 0.10 \mathrm{a}$ & $2.65 \pm 0.58 b$ & $9.03 \pm 0.44 b$ & $71.79 \pm 1.57$ & $16.53 \pm 0.55 \mathrm{~b}$ \\
\hline 2008 & $3.0 \pm 0.2 \mathrm{a}$ & $1.24 \pm 0.11 \mathrm{a}$ & $0.72 \pm 0.01 \mathrm{c}$ & $2.09 \pm 0.10 \mathrm{a}$ & $2.12 \pm 0.14 \mathrm{a}$ & $1.02 \pm 0.10 \mathrm{a}$ & $1.66 \pm 0.10 \mathrm{a}$ & $3.25 \pm 0.10 \mathrm{~b}$ & $9.06 \pm 0.20 \mathrm{~b}$ & $70.61 \pm 0.73$ & $17.08 \pm 0.43 b$ \\
\hline 2009 & $4.7 \pm 0.1 \mathrm{~d}$ & $1.15 \pm 0.04 \mathrm{a}$ & $0.68 \pm 0.01 \mathrm{~b}$ & $2.47 \pm 0.11 \mathrm{c}$ & $2.41 \pm 0.14 \mathrm{~b}$ & $1.38 \pm 0.12 c$ & $2.01 \pm 0.08 \mathrm{c}$ & $3.04 \pm 0.06 \mathrm{a}$ & $8.8 \pm 0.41 \mathrm{~b}$ & $74.41 \pm 1.03$ & $13.75 \pm 0.56 \mathrm{a}$ \\
\hline 2010 & $3.4 \pm 0.1 \mathrm{c}$ & $1.28 \pm 0.03 \mathrm{a}$ & $0.66 \pm 0.02 \mathrm{a}$ & $2.12 \pm 0.10 \mathrm{a}$ & $2.22 \pm 0.12 \mathrm{a}$ & $1.11 \pm 0.07 \mathrm{~b}$ & $1.73 \pm 0.07 \mathrm{~b}$ & $3.00 \pm 0.08 \mathrm{a}$ & $6.05 \pm 0.50 \mathrm{a}$ & $76.81 \pm 0.97$ & $14.14 \pm 0.39 \mathrm{a}$ \\
\hline 2011 & $3.5 \pm 0.1 \mathrm{c}$ & $1.26 \pm 0.01 \mathrm{a}$ & $0.66 \pm 0.01 \mathrm{a}$ & $2.20 \pm 0.09 \mathrm{~b}$ & $2.19 \pm 0.0 \mathrm{a}$ & $1.15 \pm 0.11 b$ & $1.77 \pm 0.08 \mathrm{~b}$ & $3.22 \pm 0.10 \mathrm{~b}$ & $6.52 \pm 0.35 \mathrm{a}$ & $73.5 \pm 0.78$ & $16.76 \pm 0.33 \mathrm{~b}$ \\
\hline
\end{tabular}

a Averages \pm standard deviations are reported, in dry base. Numbers with different letters in the same column for same seed origin are significantly different. $\mathrm{d} 1=$

seed width, $\mathrm{d} 2$ = seed length, e = thickness of the seed. ${ }^{\mathrm{b}}$ P, P1 and P2 Pichanan varieties; F, F1 and F2, Faro varieties; B, B1 and B2, Baer varieties, Ch: harvested in

Chile. Rc: harvested in Rio IV. ${ }^{\mathrm{c}}$ ordered by harvest year. 


\subsection{Chemical Properties}

As shown in Table 1, ash content tends to be a little higher in seeds from Centre region and the opposite seems to be happening with lipids. Calcium and Magnesium being the main components of minerals present in quinoa while heavy metals like $\mathrm{Pb}$ and $\mathrm{Cd}$ are negligible [2], which mean that this grain can be considered as a valuable source of minerals, such as $\mathrm{Ca}, \mathrm{Mg}, \mathrm{K}, \mathrm{P}, \mathrm{Fe}, \mathrm{Cu}$ and $\mathrm{Zn}$.

Quinoa oil present good nutritional qualities [9] and can be considered as having potential for oil extraction. Carbohydrate contents shown in Table 1 are lower than those of common cereals but close enough to consider the quinoa grains as similar to cereal, i.e., pseudocereal [10]. The total protein varied from 13.75 to $18.25 \%$, but quinoas from the Centre region showed rather higher value. Table 2 compares the amino acid contents for the five northern quinoas with bibliographic data for cereals and milk. The clear advantages of quinoa in histidine, methionine and lysine can be seen. In Table 3, the Chemical Scoring (CS) and Protein Digestibility Corrected Amino Acid Score (PDCAAS) of quinoa protein for preschools, schoolchildren and adults are presented. Data were calculated for 2009 and 2010 lots of northern quinoas, and in both cases the limiting amino acids were methionine and cysteine for all the age groups. Nevertheless, in seven of the amino acids of Table 3, the CS of the two quinoa batches covers $86 \%$ or more of the needs. The Protein Digestibility Corrected Amino Acid Score (PDCAAS), shown in Table 3, were estimated from a protein digestibility of $80 \%$ [11]. These results reflect the high disposability of quinoa amino acids and are similar to those from [12] in spite of these authors employing a higher factor for PDCAAS calculations.

\subsection{Products Development}

As can be seen in Table 3, quinoa is deficient in sulfur-rich amino acids, which makes it necessary to improve the nutritional quality of quinoa products by appealing to other grains, such as legumes. Accordingly, a batter-type gluten-free bread, with quinoa and lupin as the main ingredients, was developed, including $41 \%$ of quinoa, $29 \%$ of rice and $18 \%$ of lupin flours. This formulation has notable advantages when compared with commercial breads This formulation has notable advantages when compared with commercial breads, such as reducing carbohydrates and lipids and at the same time, increasing the polypeptides' content. The presence of sulfur-rich amino acids and also of histidine and serine are important. The final formulation was the result of many assays in which the effect of the main flours and minor components such as starches, gums, stabilizer, antioxidants and preservatives were statistically evaluated through experimental mixture designs. It was observed that water content and granulometry of the quinoa meal directly influenced the firmness and specific volume, while leavening and hydrocolloids other than HPMC did not have a significant effect on the quality of the loaves.

Leavening and hydrocolloids other than HPMC did not have a significant effect on the quality of the loaves. Between the emulsifiers, just SSL improved the texture, the specific volume and structure of the bread crumb. The incorporation of defatted flours of quinoa and lupine improved bread flavor, but it made the structure collapse [13]. The optimized formulation almost doubles the protein content of commercial quinoa breads and, at the same time, exhibits lower levels of lipids and carbohydrates, with higher content of essential amino acids. Despite being in the lowest proportion, lupin is the main protein source in the formula. The actual offer in gluten-free products is superabundant in carbohydrates and poor in proteins, as some studies show [14]; alternatives such as those described above tend to overcome the problem. 
Table 2. Amino acid profiles of western quinoa seeds.

\begin{tabular}{|c|c|c|c|c|c|c|c|c|c|c|c|c|}
\hline Amino Acid & 2007 & 2008 & 2009 & 2010 & 2011 & Quinoa $^{a}$ & Wheat a & Rice a & Oats a & Corn ${ }^{a}$ & Barley a & Milk a $^{a}$ \\
\hline aspartic acid & $1.07 \pm 0.00$ & $0.69 \pm 0.04$ & $1.09 \pm 0.06$ & $0.84 \pm 0.04$ & $1.14 \pm 0.07$ & 0.88 & 0.49 & 0.81 & 1.06 & 0.60 & 0.67 & 0.26 \\
\hline glutamic acid & $1.87 \pm 0.00$ & $1.81 \pm 0.04$ & $1.90 \pm 0.1$ & $1.47 \pm 0.04$ & $2.24 \pm 0.07$ & 1.43 & 4.17 & 1.62 & 2.92 & 1.80 & 2.77 & 0.76 \\
\hline serine & $0.39 \pm 0.00$ & $0.15 \pm 0.00$ & $0.55 \pm 0.03$ & $0.11 \pm 0.03$ & $0.57 \pm 0.24$ & 0.44 & 0.56 & 0.43 & 0.66 & 0.47 & 0.48 & 0.20 \\
\hline histidine & $0.40 \pm 0.00$ & $0.29 \pm 0.01$ & $0.40 \pm 0.02$ & $0.90 \pm 0.03$ & $0.79 \pm 0.53$ & 0.29 & 0.25 & 0.2 & 0.29 & 0.26 & 0.25 & 0.09 \\
\hline glycine & $0.69 \pm 0.00$ & $0.50 \pm 0.01$ & $0.78 \pm 0.04$ & $0.66 \pm 0.02$ & $0.59 \pm 0.26$ & 0.62 & 0.42 & 0.39 & 0.66 & 0.35 & 0.45 & 0.07 \\
\hline threonine & $0.43 \pm 0.00$ & $0.19 \pm 0.00$ & $0.43 \pm 0.02$ & $0.35 \pm 0.02$ & $0.61 \pm 0.27$ & 0.42 & 0.32 & 0.31 & 0.46 & 0.34 & 0.39 & 0.15 \\
\hline arginine & $1.04 \pm 0.00$ & $0.87 \pm 0.00$ & $1.15 \pm 0.08$ & $0.89 \pm 0.04$ & $1.34 \pm 0.07$ & 0.84 & 0.42 & 0.65 & 0.88 & 0.40 & 0.56 & 0.11 \\
\hline alanine & $0.58 \pm 0.00$ & $0.65 \pm 0.01$ & $0.58 \pm 0.03$ & $0.48 \pm 0.01$ & $0.54 \pm 0.44$ & 0.56 & 0.37 & 0.47 & 0.63 & 0.72 & 0.46 & 0.12 \\
\hline proline & $0.77 \pm 0.00$ & $0.55 \pm 0.02$ & $0.35 \pm 0.06$ & $0.09 \pm 0.03$ & $1.48 \pm 0.06$ & 0.37 & 1.39 & 0.37 & 0.72 & 0.85 & 1.28 & 0.31 \\
\hline tyrosine & $0.34 \pm 0.01$ & $0.07 \pm 0.01$ & $0.32 \pm 0.02$ & $0.28 \pm 0.01$ & $0.26 \pm 0.01$ & 0.34 & 0.28 & 0.28 & 0.46 & 0.36 & 0.37 & 0.16 \\
\hline valine & $0.62 \pm 0.01$ & $0.12 \pm 0.01$ & $0.71 \pm 0.08$ & $0.56 \pm 0.07$ & $0.50 \pm 0.01$ & 0.54 & 0.49 & 0.43 & 0.71 & 0.46 & 0.59 & 0.20 \\
\hline methionine & $1.26 \pm 0.01$ & $0.78 \pm 0.03$ & $0.13 \pm 0.01$ & $0.11 \pm 0.03$ & $1.51 \pm 0.34$ & 0.24 & 0.17 & 0.18 & 0.23 & 0.18 & 0.20 & 0.09 \\
\hline cysteine & $0.27 \pm 0.01$ & $1.64 \pm 0.08$ & $0.06 \pm 0.00$ & $0.04 \pm 0.00$ & $0.69 \pm 0.01$ & --- & 0.30 & 0.08 & 0.37 & 0.15 & 0.27 & 0.03 \\
\hline isoleucine & $0.53 \pm 0.01$ & $0.44 \pm 0.01$ & $0.53 \pm 0.03$ & $0.43 \pm 0.01$ & $0.64 \pm 0.01$ & 0.43 & 0.44 & 0.30 & 0.53 & 0.35 & 0.42 & 0.16 \\
\hline leucine & $0.86 \pm 0.01$ & $0.66 \pm 0.02$ & $0.88 \pm 0.05$ & $0.71 \pm 0.02$ & $1.01 \pm 0.02$ & 0.72 & 0.84 & 0.65 & 1.01 & 1.19 & 0.78 & 0.33 \\
\hline phenylalanine & $0.52 \pm 0.01$ & $0.31 \pm 0.01$ & $0.52 \pm 0.03$ & $0.43 \pm 0.01$ & $0.58 \pm 0.02$ & 0.49 & 0.58 & 0.41 & 0.70 & 0.46 & 0.60 & 0.19 \\
\hline lysine & $0.63 \pm 0.00$ & $0.49 \pm 0.01$ & $0.60 \pm 0.03$ & $0.60 \pm 0.02$ & $0.78 \pm 0.01$ & 0.67 & 0.25 & 0.30 & 0.52 & 0.25 & 0.41 & 0.27 \\
\hline
\end{tabular}

a FAO. United Nations Organization for Agriculture and Food. Food and nutrition collection (1970). Content in the amino acids of food and biological data on proteins. Rome Italy. Results expressed in $\mathrm{g} / 100 \mathrm{~g}$ of seed four. 
Table 3. Chemical Scoring (CS) a and protein digestibility corrected amino acid score (PDCAAS) of quinoa protein.

\begin{tabular}{|c|c|c|c|c|c|c|}
\hline \multirow{2}{*}{ Amino Acids } & \multicolumn{3}{|c|}{ Year 2010} & \multicolumn{3}{|c|}{ Year 2009} \\
\hline & Pre-School Chillaren & School Children & Adults & Pre-School Children & School Children & Adults \\
\hline & 2-5 Years Old & 10-12 Years Old & & 2-5 Years Old & 0-12 Years Old & \\
\hline Histidine & 400 & 400 & 475 & 136.8 & 136.8 & 162.5 \\
\hline Isoleucine & 128.6 & 128.6 & 276.9 & 125 & 110.7 & 269.2 \\
\hline Leucine & 90.9 & 136.4 & 315.8 & 87.9 & 131.8 & 305.3 \\
\hline Lysine & 86.9 & 114.5 & 315 & 69 & 90.9 & 250 \\
\hline Methionine \pm Cysteine ${ }^{b}$ & 50.8 & 57.7 & 74.7 & 59.2 & 67.3 & 87.1 \\
\hline Phenylalanine \pm Tyrosine & 95.4 & 273.2 & 316.3 & 88.9 & 254.5 & 294.7 \\
\hline Threonine & 86.2 & 104.6 & 325.6 & 82.4 & 100 & 311.1 \\
\hline Tryptophan & $\mathrm{s} / \mathrm{d}$ & $\mathrm{s} / \mathrm{d}$ & $\mathrm{s} / \mathrm{d}$ & 427.3 & 522.2 & 940 \\
\hline Valine & 134 & 187.6 & 360.8 & 217.1 & 304 & 584.6 \\
\hline Chemical Scoring & 50.8 & 57.7 & 74.7 & 67.3 & 59.2 & 87.1 \\
\hline PDCAAS $^{c}$ & 40.6 & 46.2 & 59.8 & 47.4 & 53.8 & 69.7 \\
\hline
\end{tabular}

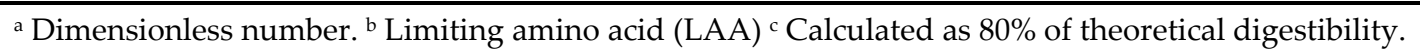


Malting is the result of allowing a controlled seed germination, during this process many nutritious substances are released, particularly small sugars, amino acids and peptides [15], easily absorbed by the gut [10]. Muffins are batter-type formulations similar to the above-described bread [8], commonly consumed for breakfast and snacks. In muffins, the leavening stage is not needed and, after shaking, the batter is directly baked and then cooled at room temperature. Three formulations were assayed, with 30\% quinoa (whole flour, and germinated whole flours for 24 and $72 \mathrm{~h}$ ) and $70 \%$ rice flours and compared with a control muffin made just with rice flour. While the taste and flavor of rice muffin was preferred, that with quinoa flour germinated for $24 \mathrm{~h}$ presented a good taste and a texture barely less accepted than the control. Non-germinated quinoa flour formulation had negative comments regarding a bitter aftertaste, making it not eligible. The muffin formulation made with flour of quinoa germinated during $72 \mathrm{~h}$ presented a disgusting taste, frequently described as strong vegetal-like aftertaste, and it was also discarded. It is possible that the bitter taste in the first case was due to residual saponins present in seeds, but the unpleasant flavor perceived in the last one should be related to the germination process and the release of new substances. Untrained judges are often not familiar with gluten-free products, which normally provide great sensory changes, and explain their preferences for rice formulation. The slight disadvantage in flavor of the 24-h germinated formulation with respect to Control is compensated by the improvement observed at the nutritional level. As can be seen in Figure 1, quinoa protein seems to rise up until $24-48 \mathrm{~h}$ of germination, when it stabilizes, while lipids seem to keep increasing. Conversely, carbohydrates describe a negative tendency, as a consequence of the metabolic activity in seeds building, among others, proteins and lipids. Similar tendencies can be seen in Figure 2 for free essential amino acids; with the exception of valine, the others show a plateau at $24-48 \mathrm{~h}$ of germination. This behavior is also observed in the soluble matter (Figure 2), where the six substances seems to mimic their tendencies, giving flat curve segments between $24-48 \mathrm{~h}$, all maxima. Many of them are small molecules which can go across the inner gut membrane with relative facility.

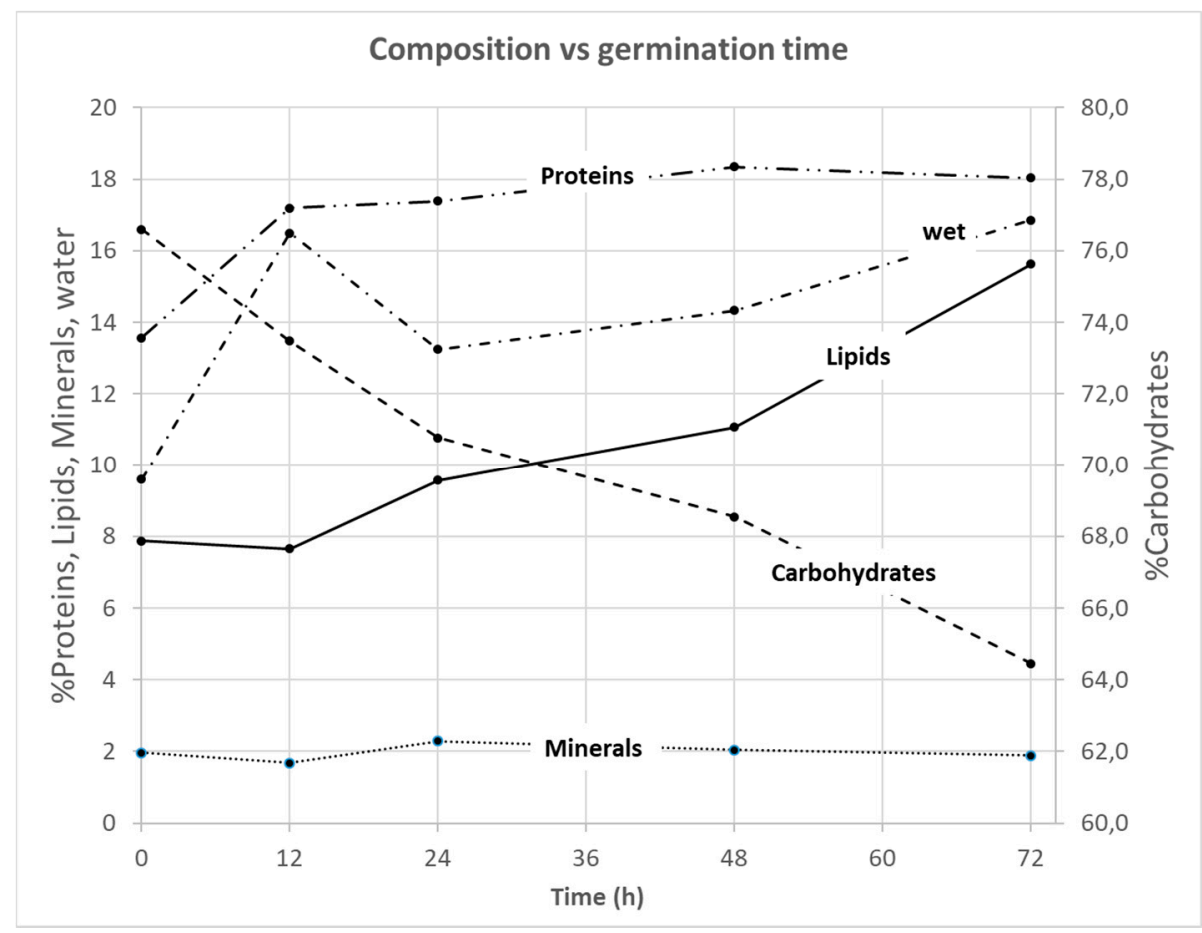

Figure 1. The change in proximate composition of quinoa flours along the germination time. All values expressed in dry base. 


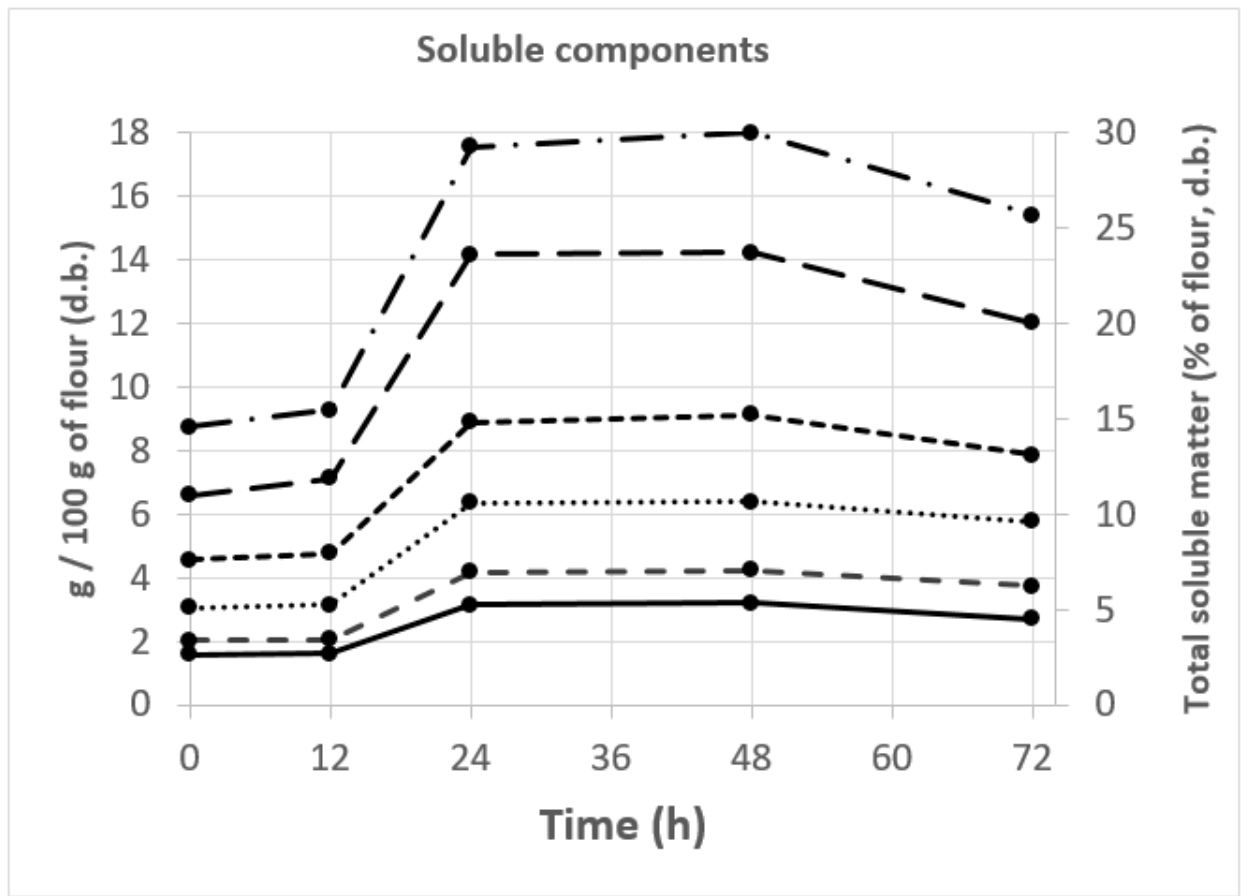

Figure 2. Changes in soluble components in quinoa flours, along the germination time.

\section{Conclusions}

In the present work, the nutritional quality of quinoa seeds and flours was shown. Quinoas from the Centre region where smaller than northern ones, with slightly higher protein content, but in all cases surpassing those of cereals. Lipid content was also greater than in cereals, and minerals ranged between $3 \%$ and $4 \%$. Quinoa protein was rich in some essential amino acids but poor in methionine and cysteine, and mixing with sulfur-rich grain, such as legumes, is recommended. Gluten-free breads prepared with a mixture of quinoa and lupine flours showed good taste and texture and an improved nutritious quality. Muffins made with malted quinoa grain flour for $24 \mathrm{~h}$ showed a higher content of essential amino acids and soluble substances of small size, easily absorbed by the gut.

Funding: Authors wish to thank the Secretary of Science and Technology of the Universidad Nacional de Córdoba for the economic support.

Acknowledgments: This work was supported by grants Ia ValSe-Food-CYTED (119RT0567) and Secretaría de Ciencia y Técnica de la Universidad Nacional de Córdoba, Argentina.

\section{References}

1. Czaja-Bulsa, G. Non coeliac gluten sensitivity-A new disease with gluten intolerance. Clin. Nutr. 2015, 34, 189-194. doi:10.1016/j.clnu.2014.08.012.

2. Vidueiros, S.M.; Curti, R.N.; Dyner, L.M.; Binaghi, M.J.; Peterson, G.; Bertero, H.D.; Pallaro, A.N. Diversity and interrelationships in nutritional traits in cultivated quinoa (Chenopodium quinoa Willd.) from Northwest Argentina. J. Cereal Sci. 2015, 62, 87-93. doi:10.1016/j.jcs.2015.01.001.

3. Renzetti, S.; Rosell, C.M. Role of enzymes in improving the functionality of proteins in non-wheat dough systems. J. Cereal Sci. 2016, 67, 35-45. doi:10.1016/j.jcs.2015.09.008.

4. Ahmad, S.; Ahmad, M.; Rashid, H.; Ahmad, I. In fl uence of hydrocolloids on dough handling and technological properties of gluten-free breads. Trends Food Sci. Technol. 2016, 51, $49-57$. doi:10.1016/j.tifs.2016.03.005.

5. Cervilla, N.; Mufari, J.; Calandri, E.; Guzmán, C. Propiedades Físicas de Semillas y Análisis proximal de harinas de Chenopodium Quinoa Willd Cosechadas en Distintos Años y Provenientes de la Provincia de Salta. II Jorn. Investig. Ing. NEA Países Limítrofes 2013, 7, 14-15. 
6. Cervilla, N.; Romina, J.; Calandri, E.; Guzman, C. Determinación del contenido de aminoácidos en harinas de quinoa de origen argentino. Evaluación de su calidad proteica. Actual. Nutr. 2012, 13, 107-113. Available online: http://www.revistasan.org.ar/pdf_files/trabajos/vol_13/num_2/RSAN_13_2_107.pdf (accessed on 13 May 2017).

7. Mufari, J.; Miranda-Villa, P.; Bergesse, A.; Cervilla, N.; Calandri, E. Physico-chemical analysis and protein fraction compositions of different quinoa cultivars. Acta Alim. 2018, 47, 462-469. doi:10.1556/066.2018.47.4.9.

8. Miranda-Villa, P.P.; Mufari, J.R.; Bergesse, A.E.; Calandri, E.L. Effects of Whole and Malted Quinoa Flour Addition on Gluten-Free Muffins Quality. J. Food Sci. 2018, 84, 147-153. doi:10.1111/1750-3841.14413.

9. Mufari, J.R.; Gorostegui, H.A.; Miranda-Villa, P.P.; Bergesse, A.E.; Calandri, E.L. Oxidative Stability and Characterization of Quinoa Oil Extracted from Wholemeal and Germ Flours. J. Am. Oil Chem. Soc. 2020, 97, 57-66. doi:10.1002/aocs.12308.

10. García Luna, P.P.; López Gallardo, G. Evaluación de la absorción y metabolismo intestinal. Nutr. Hosp. 2007, 22, 5-13.

11. Tapia, M. Cultivos Andinos Sub-Explotados y su Aporte a la Alimentación. 2000. Available online: http://www.fao.org/tempref/GI/Reserved/FTP_FaoRlc/old/prior/segalim/prodalim/prodveg/cdrom/conte nido/libro10/home10.htm (accessed on 24 March 2020).

12. Mota, C.; Santos, M.; Mauro, R.; Samman, N.; Matos, A.S.; Torres, D.; Castanheira, I. Protein content and amino acids profile of pseudocereals. Food Chem. 2016, 193, 55-61. doi:10.1016/j.foodchem.2014.11.043.

13. Miranda Villa, P.M. Efecto de la Adición de Harina de Quinoa y Lupino Dulce Sobre la Calidad Tecnológica de Panes Libres de Gluten. Ph.D. Thesis, FCEFyN-UNC, Córdoba, Argentina, 2019.

14. Naqash, F.; Gani, A.; Gani, A.; Masoodi, F.A. Gluten-free baking: Combating the challenges-A review. Trends Food Sci. Technol. 2017, 66, 98-107. doi:10.1016/j.tifs.2017.06.004.

15. Mäkinen, O.E.; Hager, A.S.; Arendt, E.K. Localisation and development of proteolytic activities in quinoa (Chenopodium quinoa) seeds during germination and early seedling growth. J. Cereal Sci. 2014, 60, 484-489. doi:10.1016/j.jcs.2014.08.009. 